\title{
Strategi Komunikasi Pemasaran Radio Andika Fm Kediri Periode Tahun 2014-2016
}

\author{
Agus Syauqi \\ IAI Pangeran Diponegoro Nganjuk
}

\begin{abstract}
ABSTRAK
Untuk menarik pengiklan dan pendengar, radio akan melakukan perubahan-perubahan. Salah satunya perubahan format siar, Andika merupakan salah satu radio yang mengganti format siarannya menjadi citizen journalism. Melihat masalah tersebut peneliti menganggap penelitian ini penting dilakukan untuk membedah bagaim bagaimana strategi komunikasi pemasaran radio Andika periode 2014-2016.

Tujuan dari penelitian ini adalah Untuk mengetahui strategi komunikasi pemasaran radio Andika periode 2014-2016 dan Untuk menjelaskan proses strategi komunikasi pemasaran radio. Penelitian ini merupakan penelitian deskriptif kualitatif dengan metode penelitian studi kasus untuk menemukan jawaban atas rumusan masalah yang diajukan.

Berdasarkan hasil penelitian dapat disimpulkan bahwa strategi pemasaran radio Andika berhasil dalam menggaet pendengar dan pengiklan. Dari hasil temuan dan analisis, peneliti merekomendasikan agar dilakukan penelitian lebih lanjut mengenai riset pendengar untuk mengetahui apa yang menjadi harapan audiens dari mendengarkan radio Andika.

Kata Kunci : Radio, strategi komunikasi pemasaran, Format, pengiklan.
\end{abstract}

\section{PENDAHULUAN}

Stasiun penyiaran swasta adalah lembaga penyiaran yang bersifat komersil berbentuk badan hukum Indonesia yang bidang usahanya hanya menyelenggarakan jasa penyiaran Radio atau televisi (Undang-undang Penyiaran no. 32, 2002, pasal 13). Dalam website Kominfo, Industri penyiaran Indonesia berkembang pesat pasca runtuhnya rezim Orde Baru pada tahun 1998. Indonesia memiliki 6 stasiun televisi pada tahun 2008, dan tahun 2012 memiliki 62 stasiun 
$\int \begin{aligned} & \text { p-ISSN: } 2723-4703 \\ & \text { e-ISSN: }- \\ & \text { http://ejurnal.iaipd-nganjuk.ac.id/index.php/j-kis/ } \\ & \text { KURNAL }\end{aligned}$

(Data Ditjen PPI, 2012). Jumlah stasiun Radio juga meningkat dari 700 stasiun Radio pada akhir 2010 terdapat sekitar 2590 lembaga penyiaran Radio yang berproses di Kemkominfo (Data PRSSNI 2011). endengar, Radio merupakan media untuk mendapatkan informasi dan hiburan.

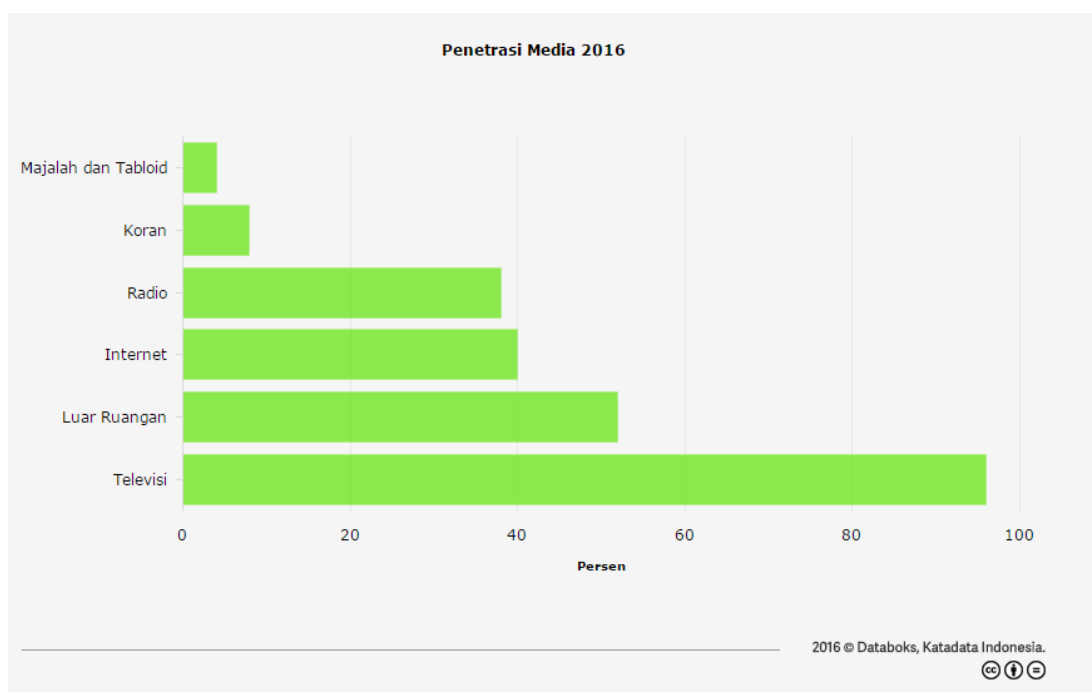

Gambar 1.1 Penetrasi media Nielsen

Sejalan dengan perkembangan jumlah Radio, Nielsen memberikan riset mengenai jumlah penetrasi pendengar Radio di Indonesia mencapai 38 persen atau sekitar 20 juta orang, jauh melebihi koran dan majalah. Dari data tersebut Radio masih memiliki tempat dimasyarakat, meskipun terdapat banyak persaingan dengan media lain. Survei Radio Audience Measurement (RAM) 2016 yang dilakukan oleh Nielsen semester awal 2016, belanja iklan Radio mengalami pertumbuhan yaitu sebesar Rp. 57 miliar. Hal ini menunjukkan Radio masih dianggap salah satu media yang efektif untuk memperkenalkan produk kepada konsumen segmen tertentu. Sementara bagi pendengar, Radio merupakan media untuk mendapatkan informasi dan hiburan. 


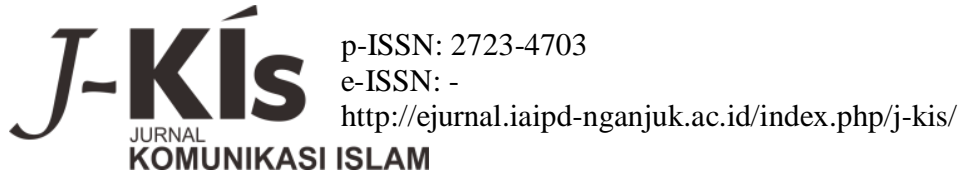

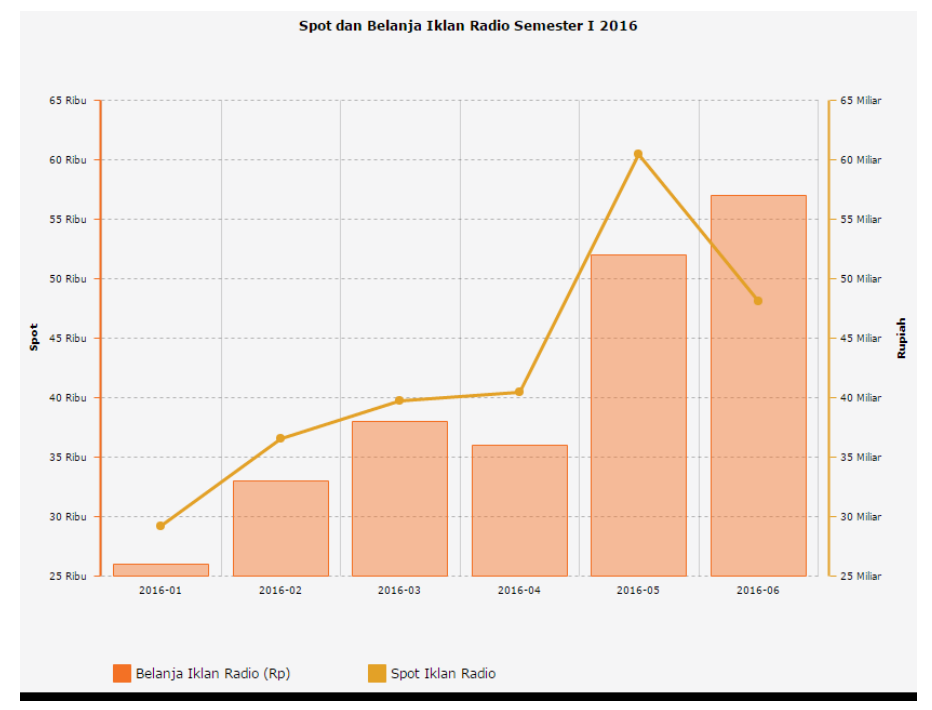

Gambar 2: spot dan belanja iklan Radio semester I 2016

Tak hanya persaingan dengan media penyiaran lain baik Tv atau internet, Radio memiliki persaingan ketat dengan Radio lain dalam memperebutkan audien dan pengiklan. Morissan memaparkan bahwa di dalam dunia penyiaran audien adalah pasar, dan program yang disajikan adalah produk yang ditawarkan (morisan,2009, p.165). Picard dalam jurnal komunikasi universitas Atma Jaya (Setio, 2004, p. 5) menunjukkan bahwa dalam istilah ekonomi, industri media muncul dan beroprasi dalam apa yang disebut dual product market, yaitu menciptakan satu produk, yaitu media itu sendiri dan berada dalam dua pasar yaitu pasar khalayak dan pasar iklan. Hubungan antara pertumbuhan industri media dan khalayak berdasar pada komodifikasi (nilai komersil) sosial yaitu informasi dan hiburan. Sementara hubungan antar pertumbuhan industri dan periklanan berkaitan dengan acces to customer. Sehingga dalam memenuhi kebutuhan pengiklan dalam memasarkan produknya, perusahaan penyiaran melakukan strategi-strategi dalam menarik pendengar. Salah satu strategi yang dilakukan adalah merubah format siar, agar sesuai dengan kebutuhan audien dari pengiklan. Salah satu Radio yang merombak format siarannya adalah Radio Andika Kediri.

Pada mulanya Radio Andika mengudara dengan dengan format yang umumnya di gunakan radio-radio di wilayah Kediri yaitu dengan motto menghibur, informatif dan solutif dibingkai religi kuat dan budaya yang lekat, dimana isi siarannya adalah gado-gado atau campur-campur. Dalam format tersebut acara yang disajikan berupa guyonan, drama radio, dangdutan dan ceramah agama. 


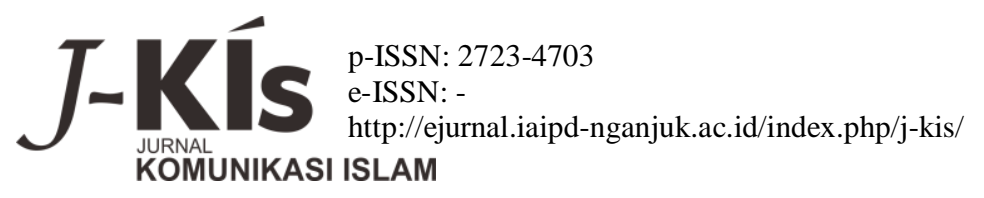

Kemudian pada tahun 2014 saat gunung kelud meletus, banyak laporan yang disampaikan oleh pendengar mengenai keadaan terkini di wilayahnya. Keadaan bangunan, jalan, maupun distribusi bantuan yang tersendat. Peristiwa tersebut menjadi titik awal perubahan Radio Andika menuju format yang benar-benar berbeda. Radio Andika merubah wajahnya dengan mengembangkan format baru dan satu-satunya di wilayah Kediri yaitu Radio citizen journalism.

Perubahan format tentunya membutuhkan keberanian, resiko kegagalan selalu ada, akan tetapi hal tersebut merupakan tantangan bagi Radio Andika untuk mengenalkan format barunya di khalayak sehingga dapat diterima dengan baik. Tidak hanya diterima dengan baik oleh masyarkat, format baru ini membutuhkan partisipasi masyarakat dalam menjalankan programnya. Peran masyarakat dalam format baru ini adalah sebagai sumber informasi, sebagai penyampai pesan atau sebagai pelapor suatu informasi.

Untuk dapat mencapai tujuan tersebut, maka perlu didukung dengan promosi format baru, sebagai bagian dari strategi komunikasi pemasaran. Promosi dalam industri penyiaran, memiliki perbedaan dengan promosi industri yang dilakukan oleh perusahaan yang menjual barang pada umumnya. Promosi yang dilakukan Radio ditujukan untuk menarik audiens dan menarik pengiklan.

Dari prapenelitian, perubahan yang dilakukan Andika memberikan dampak positif tehadap pendengar, dan berpengaruh terhadap jumlah pengiklan. Dari tahun ketahun setelah perubahan, jumlah pendapatan dari iklan selalu melebihi dari target yang di tentukan. Hal tersebut menunjukkan kesuksesan stategi pemasaran yang dilakukan oleh Radio Andika dalam mengenalkan wajah barunya.

Berdasarkan uraian diatas, penulis merasa perlu untuk mengkaji lebih jauh mengenai strategi pemasaran pemasaran Radio Andika Perkembangan media komunikasi modern dewasa ini telah memungkinkan orang di seluruh dunia untuk dapat saling berkomunikasi. Hal ini dimungkinkan karena adanya berbagai media yang bdapat digunakan sebagai sarana penyampaian pesan. Media penyiaran, yaitu radio dan televisi merupakan salah satu bentuk media massa yang efisien dalam mencapai audiennya dalam jumlah yang sangat banyak. Karenanya media penyiaran memegang peranan yang sangat penting dalam ilmu komunikasi pada umumnya dan khususnya ilmu komunikasi massa. (Morissan, 2009) 


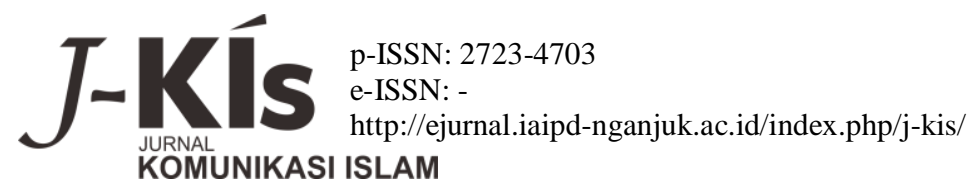

Dalam buku Jurnalisme Radio Teori dan Praktik, dijelaskan bahwa radio adalah buah perkembangan teknologi yang memungkinkan suara ditransmisikan secara serempak melalui gelombang radio di udara. Tahun 1896, Guglielmo Marconi menciptakan wireless telegraph yang menggunakan ngelombang radio untuk membawa pesan dalam bentuk kode Morse. Marconi lantas mendirikan perusahaan pengirim pesan kedatangan dan keberangkatan kapal, mendirikan stasiun pemancar dan penerima,tertama di kawasan yang tidak terjangkau kabel telegraf, dan belakangan bahkan mendirikan pabrik perakit dan penyedia perlengkapan radio. Radio memiliki sejumlah fungsi, seperti mentransmisikan pesan, membidik, membujuk, dan menghibur. Dalam memnyampaikan pesannya, radio bisa mengambil model komunikasi apa saja. Entah model searah, maupun dua arah. Model satu arah mengasumsikan bahwa radio sebagai komunikator yang melakukan interaksi timbal balik dengan khalayak aktif. Kecenderungannya memang kini lebih banyak acara - acara interaktif di radio. (Santi Indra Astuti, 2008)

Media penyiaran memerlukan promosi baik untuk mendapatkan pendengar maupun pengiklan. Tempat terbaik untuk mempromosikan program adalah tentu saja di stasiun sendiri. Promosi di stasiun sendiri merupakan cara yang paling cepat dan paling mudah dilakukan karena audien sedikit banyak sudah tersedia. Promosi program merupakan seni untuk membuat audien tidak pindah ke stasiun penyiaran lain. Promosi di media penyiaran sendiri bertujuan memberi tahu dan mengingatkan audien untuk terus mengikuti program lain yang akan atau segera ditayangkan. Cara media berpromosi akan menentukan apakah suatu program akan berhasil atau gagal, karena itu media penyiaran tidak boleh meremehkan pentingnya tugas promosi ini. Media penyiaran dapat mempromosikan berbagai programnya setiap hari. beberapa faktor yang harus diperhatikan agar promosi di media sendiri dapat mencapai hasil optimal yaitu: (Morrisan, 2009 : 422)

1. Media penyiaran harus menunjukkan identitas diri mereka pada setiap kesempatan. Stasiun radio harus cukup sering mengudarakan jinggel radio yang menjadi identitas radio bersangkutan, sedangkan penyiar radio harus cukup sering mengucapkan kata-kata promosi yang menunjukkan identitas radio.

2. Logo merupakan simbol stasiun televisi, sedangkan jinggel menjadi ciri stasiun radio. Logo dan jinggel harus dibuat secara cermat hingga selalu menarik hingga kapan pun juga. Bagian 
promosi stasiun televisi harus memastikan bahwa logo selalu terpasang di sudut layar televisi.

3. Logo juga dapat dipasang di berbagai benda yang akan dilihat publik: alat-alat tulis, mesin faks, buku agenda, buku catatan reporter, kamera, di kendaraan seperti mobil dan truk dan juga pada saat pemasangan iklan di media cetak. Bila stasiun televisi memberi hadiah kepada tamunya, maka pasang logo pada hadiahnya.

4. Selain logo, stasiun radio dan televisi juga dapat menciptakan slogan berupa kata-kata yang memiliki pengertian yang menggambarka karakter stasiun televisi dan radio bersangkutan. Untuk radio, slogan yang digunakan hendaknya mencerminkan format stasiun bersangkutan. Penggunaan slogan dapat menjadi cara yang efektif untuk mempromosikan citra (image) stasiun penyiaran.

5. Setiap jeda iklan sebaiknya memasukkan sekurang-kurangnya satu sampai tiga promosi yang mengumumkan suatu program yang akan ditayangkan dengan cara menampilkan cuplikannya. Frekuensi promosi program harus cukup sering dilakukan agar audien yang tengah mengikuti stasiun bersangkutan dapat menerima informasi dari promosi yang ditayangkan itu setidaknya satu kali.

6. Promosi untuk program hiburan biasanya dilakukan dengan cara menampilkan cuplikan (klip) program bersangkutan. Promosi program hiburan yang efektif-khususnya program berseri - adalah dengan menampilkan klip dan episode yang akan segera ditayangkan (specific promo) dan bukan hanya dan satu jenis klip yang diputar berulang-ulang. Jika program yang dipromosikaii itu adalah film, maka promosi yang baik adalah menampilkan kekuatan dan keistimewaan film itu. Misalnya penghargaan yang diterima, kualitas para pemainnya atau komentar dan kritisi film, yang memuji film bersangkutan.

7. Untuk televisi, rangkaian gambar berupa cuplikan program yang dipersiapkan untuk menginformasikan audien agar menonton acara dimaksud harus dilengkapi tulisan yang menunjukkan hari dan waktu program itu akan ditayangkan.

8. Dalam upaya menjaga audien, media penyiaran harus bertindak tepat waktu dalam menayangkan suatu acara. Program yang di promosikan akan disiarkan pada jam 20.00 harus ditayangkan tepat jam 20.00, bukan 20.01 atau 19.59. Karena setiap program memiliki pesaing. Keterlambatan penayangan suatu acara akan memancing audien untuk mengalihkan 


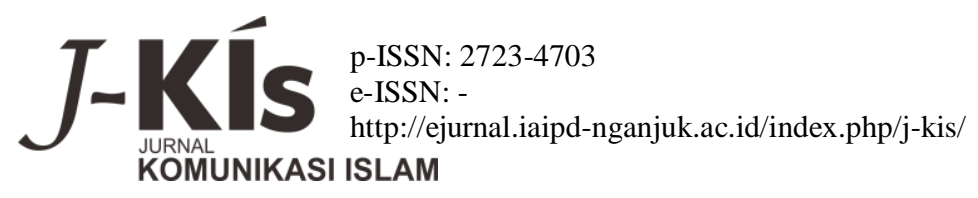

saluran ke stasiun lain dan ini bisa menghilangkan kesempatan untuk merebut audien. Upayakan untuk mengatur waktu tayang pada waktu atau jam yang genap sehingga gampang diingat.

9. Bagian promosi membutuhkan staf dan peralatan untuk memproduksi berbagai promosi program. Stasiun televisi besar, biasanya mengalokasikan satu atau dua ruang editing khusus untuk membuat promosi. Namun jika tidak terdapat ruang editing khusus, maka bagian promosi dapat menggunakan ruang editing dan peralatan milik bagian pemberitaan untuk membuat promosi. Waktu yang bisa digunakan mungkin pada dini hari, ketika hagian pemberitaan tidak sibuk bahkan tidak bekerja sehingga bagian promosi dapat memanfaatkan fasilitas yang tidak tcrpakai. Satu produser dan satu editor sudah cukup untuk menghasilkan sejumlah promosi program.

10. Promosi media penyiaran sebaiknya memiliki satu jenis suara. Dengan demiklan, hanya ada satu suara yang diasosiasikan dengan semua promo. Narator tunggal dengan suara yang berbeda dan narator lainnya (laki-laki atau perempuan) menjadi identitas audio suatu media penyiaran.

\subsection{BAURAN PEMASARAN}

Terence A.Shimp berpendapat bahwa, komunikasi pemasaran dapat dipahami dengan menguraikan dua unsur pokoknya, yaitu komunikasi dan pemasaran. Komunikasi adalah proses di mana pemikiran dan pemahaman disampaikan antar individu, atau antara organisasi dengan individu. Pemasaran adalah sekumpulan kegiatan di mana perusahaan dan organisasi lainnya mentransfer nilai-nilai (pertukaran) antara mereka dengan pelanggannya. Tentu saja, pemasaran lebih umum pengertiannya daripada komunikasi pemasaran, namun kegiatan pemasaran banyak melibatkan aktivitas komunikasi. Jika digabungkan, definisi komunikasi pemasaran menurut Terence A.Shimp ialah mempresentasikan gabungan semua unsur dalam bauran pemasaran merek, yang memfasilitasi terjadinya pertukaran dengan menciptakan suatu arti yang disebarluaskan kepada pelanggan atau kliennya. (Terence, 2003, p.04)

Istilah promosi dengan komunikasi pemasaran disamaartikan disini. Crosier menjelaskan bahwa istilah-istilah tersebut sering disamaartikan karena terdapat konteks 
pengertian yang sama dalam memahami proses untuk konteks pijakan dasar 4P (Price, Place, Product, Promotion). Dengan demikian, meskipun bauran promosi merupakan aktivitas komunikasi utama perusahaan, seluruh bauran pemasaran harus dikoordinasikan untuk mencapai dampak komunikasi yang sebenar-benarnya. (Machfoedz, 2010 , p.30-50). Berikut adalah penjelasan dari 4P dalam proses pemasaran.

\section{Produk}

Produk adalah merupakan titik sentral dari kegiatan marketing. Semua kegiatan marketing lainyya digunakan untuk menunjang pemasaran produk(Prof. Dr. Buchari, 2007, p.202). Definisi lain Produk adalah materi program yang dipilih dan memenuhi harapan audiens yang menjadi target sasaran (Morissan, 2008 : 201).Satu hal yang perlu diingat ialah bagaimana pun hebatnya usaha promosi distribusi dan harga yang baik jika tidak diikuti oleh produk yang bermutu dan disenangi oleh konsumen maka kegiatan marketing mix ini tidak akan berhasil.

Program radio sebenarnya terdiri atas tiga kategori besar format program, yaitu informasi, diskusi publik, musik, dan format khusus. Kedua jenis ini kemudian dikemas dalam berbagai bentuk yang intinya harus dapat memenuhi kebutuhan audiens dalam hal musik dan informasi (Morissan, 2008, p.224)

\section{Price}

Price memiliki andil dalam sebuah keberhasilan pemasaran suatu produk. Menurut Morrisan price adalah biaya yang harus dikeluarkan untuk memproduksi atau membeli program sekaligus menentukan tarif iklan bagi pemasang iklan yang berminat memasang iklan pada program bersangkutan (Morissan, 2008 : 202).

Harga disini bukan berarti harga yang murah saja atau harga yang tinggi akan tetapi yang dimaksud adalah harga yang tepat. Dalam perusahaan penyiaran banyak faktor yang mempengaruhi nilai harga suatu program diantaranya adalah waktu tayang suatu program. Menurut Morrisan, prime timeradio berbeda dengan televisi yang berada pada jam 19.0023.00 pada saat waktu premium ini televisi mengenakan taris paling mahal. Sedangkan untuk radio, prime time terjadi pada pagi hari dan sore hari yaitu saat orang berangkat kekantor atau pulang dari kantor dengan menumpang mobil pribadi. Sedangkan eatu 
terendah pendengar radio terjadi pada malam hariyaitu ketika sebagian besar orang menonton televisi.

\section{Place/distribution}

Place atau distribution memiliki pemahaman yaitu tahap pendistribusian produk. Saat ini kehadiran internet mengubah konsep place sebagai distribusi yang lebih efektif dibandingkan distribusi konvensional dalam menarik konsumen (Albarran, 2010 ; 194). Dalam menyebarkan konten media menurut Negroponte (1995) perkembangan inovasi dalam perangkat teknologi pada unit bisnis memiliki kecepatan yang luar biasa, transformasi pengiriman konten ke elektronik dan saluran yang kita pilih sudah dipercepat (Lawson \& Borders, 2009 ; 92)

\section{Promotion}

Selanjutnya atau yang terahir adalah promotion/promosi, menurut Terance promosi mengacu kepada setiap insentif yang digunakan, pengecer, dan bahkan prganisasi non-profit, untuk mengubah persepsi mengenai harga atau nilai merek sementarawaktu . ( Terence, 2014, p.485) .

Promotion merupakan aktivitas terpadu dalam menyampaikan kesadaran pada konsumer atau audiens serta penjualan produk secara nyata. Ada sejumlah bentuk kegiatan promosi yang ditawarkan Albarran (2010 ; 214 ) dalam membidik audiens ataupun pengiklan.

\subsection{BAURAN PROMOSI PROGRAM}

Pelaksanaan bauran pemasaran pada media penyiaran di tujukan untuk menarik minat audien untuk mendengar program yang disiarkan sekaligus manarik pemasang iklan untuk mensuport program. Bauran komunikasi pemasaran program dan media penyiaran adalah sebuah kegiatan untuk mempertahankan audien dan menarik audien baru serta mengundang pemasang iklan. Kegiatan ini mengarah kepada dua pihak, yaitu audien dan pemasang iklan. Keduanya menjadi kontributor penting dalam menjamin kelanjutan operasional media penyiaran. Tanpa adanya audien, program yang sangat bagus sekalipun 
tidak akan mampu menarik pemasang iklan dalam jumlah yang berarti. Melalui promosi, media penyiaran berupaya membujuk khalayak untuk mengikuti program-program yang disiarkan sekaligus membujuk pemasang iklan untuk membeli waktu siaran yang tersedia.

Michael Ray mendefinisikan promosi sebagai: "the coordina tion of all seller-iniated efforts to set up channels of information and persuasion to sell goods and services or promote an idea."1 (koordinasi dari seluruh upaya yang dimulai pihak penjual untuk membangun berbagai saluran informasi dan persuasi untuk menjual barang dan jasa atau memperkenalkan suatu gagasan). Komunikasi antara perusahaan media penyiaran dengan audien dan pemasang iklan pada dasarnya berlangsung pada setiap unsur atau bagian dari marketing mix, namun sebagian besar komunikasi perusahaan berlangsung sebagai bagian dari suatu program promosi yang diawasi dan direncanakan dengan hati-hati. Instrumen dasar yang digunalcan untuk mencapai tujuan komunikasi perusahaan disebut dengan Bauran promosi atau promotional mix. (Morrisan, 2009 : 420)

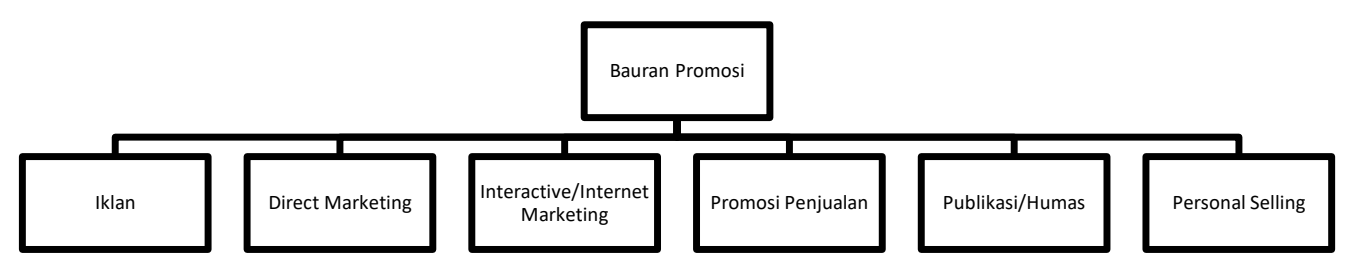

\section{Gambar: Bauran promosi}

Tidak ada batasan mengenai metode apa saja yang dapat digunakan untuk mempromosikan program dan media penyiaran. Metode promosi yang digunakan media penyiaran untuk mencapai tujuan promosinya, pada dasarnya hanya dibatasi oleh daya imajinasi orang-orang yang terlibat dalam kegiatan promosi itu. Dengan demiklan, bentuk atau metode promosi yang digunakan sangat luas selama tersedia dana untuk melakukan itu semua.

Namun demikian, terdapat empat metode utama yang banyak digunakan media penyiaran untuk melakukan promo si yaitu;

1. Memasang iklan;

2. Public Relation atau hubungan masyarakat; dan

3. Promosi di media sendiri. 


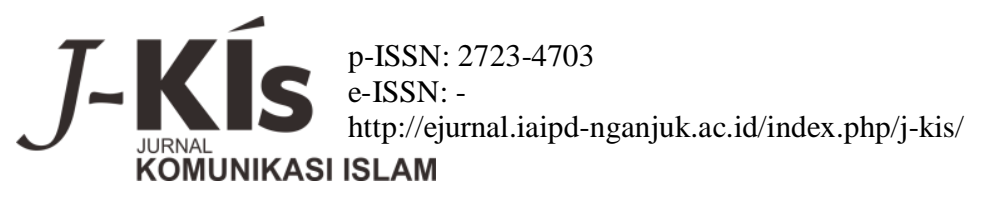

Dalam praktiknya ketiga metode promosi ini dapat dikombinasikan satu dengan lainnya.

Secara sederhana, bauran promosi mencakup empat elemen yaitu: Iklan, Promosi Penjualan, Publikasi/humas dan personal selling. Namun George dan Michael menambahkan dua elemen dalam bauran promosi, yaitu direct marketing dan interactiv media. Dua elemen yang terakhir ini telah digunakan secara luas oleh pengelola pemasaran dewasa ini untuk berkomunikasi dengan khalayak sasarannya sebagaimana empat elemen sebelumnya.

\subsection{IKLAN}

Iklan atau advertising dapat didefinisikan sebagai "any paid form of nonpersonal communication about an organization, product, service, or idea by an identified sponsor." (setiap bentuk komunikasi nonpersonal mengenai suatu organisasi, produk, servis atau ide yang dibayar oleh satu sponsor yang diketahui). Adapun maksud 'dibayar' pada definisi tersebut menunjukkan fakta bahwa ruang atau waktu bagi suatu pesan iklan pada umumnya harus dibeli. Maksud kata 'nonpersonal' berarti suatu iklan melibatkan media massa (TV, radio, majalah, koran) yang dapat mengirimkan pesan kepada sejumlah besar kelompok individu pada saat bersamaan. Dengan demiklan, sifat non- personal iklan berarti pada umumnya tidak tersedia kesempatan untuk mendapatkan umpan balik yang segera dan penerima pesan (kecuali dalam hal direct response advertising). Karena itu, sebelum pesan iklan dikirimkan, pemasang iklan harus betul-betul mempertimbangkan bagaimana audien akan menginterpretasikan dan memberikan respons terhadap pesan iklan dimaksud.

Iklan di media massa dinilai efisien dan segi biaya untuk mencapai audien dalam jumlah besar. Iklan di media massa dapat digunakan untuk menciptakan citra merek dan daya tarik simbolis bagi suatu perusahaan atau merek. Hal ini menjadi sangat penting khususnya bagi produk yang sulit dibedakan dan segi kualitas maupun fungsinya dengan produk saingannya. Pemasang iklan harus dapat memanfaatkan iklan di media massa untuk memosisikan produknya di mata konsumen.

Keuntungan lain dan iklan melalui media massa adalah kemampuannya menarik perhatian konsumen terutama produk yang iklannya populer atau sangat dikenal masyarakat. Hal ini tentu saja pada akhirnya akan meningkatkan penjualan. Sifat dan tujuan iklan 
berbeda antara satu perusahaan dengan perusahaan lainnya, antara satu jenis industri dengan industri lainnya, dan antara satu situasi dengan situasi lainnya. Demiklan juga, audien yang menjadi target suatu iklan juga berbeda antara satu jenis produk dengan produk lainnya. Suatu perusahaan beriklan dengan tujuan untuk mendapatkan respons atau aksi segera melalui iklan media massa. Perusahaan lain mungkin bertujuan untuk lebih mengembangkan kesadaran atau ingin membentuk suatu citra positif dalam jangka panjang bagi barang atau jasa yang dihasilkannya.

Melakukan promosi melalui iklan, berarti membeli waktu atau tempat pada media lain. Dalam beberapa kasus, stasiun penyiaran melakukan barter dari pada melakukan pembayaran. Ini berarti dua media massa saling bergantian memasang iklan di medianya masing-masing tanpa harus saling membayar. Misalnya stasiun televisi pasang iklan di surat kabar dan sebagai kompensasinya surat kabar melakukan promosi di stasiun penyiaran itu. Di antara media massa yang kerap digunakan media penyiaran untuk melakukan promosi adalah media cetak (surat kabar dan majalah), billboard, transit, dan media penyiaran.

\subsection{PEMASARAN LANGSUNG}

Pemasaran langsung atau direct marketing adalah upaya perusahaan atau organisasi untuk berkomunikasi secara langsung dengan calon pelanggan sasaran dengan maksud untuk menimbulkan tanggapan dan/atau transaksi penjualan. Secara tradisional, pemasaran langsung belum dianggap sebagai salah satu elemen dari bauran promosi atau promotional mix. Namun karena pemasaran langsung telah menjadi bagian integral dari program IMC yang telah dilaksanakan banyak perusahaan yang sering kali melibatkan strategi, anggaran serta tujuan yang terpisah, maka perlulah kiranya kita memasukkan pemasaran langsung sebagai salah satu komponen bauran promosi.

Bagi media penyiaran pemasaran langsung mencakup kegiatan mengirim surat (direct mail) dan mengirim katalog program serta tarif slot iklan (rate card) kepada pemasang iklan atau calon pemasang iklan.

Bagi industri pada umumnya, pemasaran langsung mencakup berbagai aktivitas termasuk pengelolaan database (database management), penjualan langsung (direct selling), telemarketing dan iklan tanggapan langsung dengan menggunakan berbagai saluran 
komunikasi seperti mengirim surat langsung kepada pelanggan dan calon pelanggan atau melalui Internet, media cetak, dan media penyiaran. Cukup banyak perusahaan saat ini yang sudah tidak lagi menggunakan saluran distribusi bentuk lain dan hanya menggunakan cara pemasaran langsung dan tidak sedikit pula perusahaan yang sukses dalam melaksanakan pemasaran langsung ini.

Salah satu instrumen penting dalam pemasaran langsung adalah iklan tanggapan langsung atau direct response advertising, yaitu iklan di mana suatu produk atau program yang dipromosikan melalui media massa meminta atau mendorong audiennya untuk mendukung produk atau program bersangkutan secara langsung. Misalnya suatu stasiun televisi yang memiliki program kompetisi menyanyi mempromosikan program tersebut di surat kabar dan meminta audien untuk mengirim SMS untuk mendukung peserta favoritnya.

Secara tradisional, mengirim surat kepada pelanggan telah lama menjadi instrumen utama bagi iklan tanggapan langsung ini namun televisi dan majalah dewasa ini juga memegang peran yang semakin penting dalam mendukung iklan jenis ini.

Iklan tanggapan langsung dan bentuk-bentuk pemasaran langsung lainnya telah menjadi sangat populer dalain dua dekade terakhir ini yang disebabkan oleh perubahan gaya hidup khususnya peningkatan pendapatan rumah tangga. ini berarti adanya peningkatan penghasilan, namun tidak tersedia cukup waktu untuk berbelanja. Ketersediaan kartu kredit serta saluran telepon bebas pulsa telah membantu semakin berkembangnya sistem penjualan langsung ini. Kenyamanan yang dirasakan konsumen saat berbelanja melalui katalog atau melalui website dan melakukan pemesanan melalui surat, telepon atau Internet menjadi pendorong pertumbuhan pemasaran langsung ini secara sangat signifikan.

Instrumen dan teknik pemasaran langsung juga digunakan oleh perusahaan yang mendistribusikan produknya melalui saluran distribusi tradisional atau perusahaan yang memiliki tenaga penjualan sendiri. Pemasaran langsung memainkan peran penting dalam program komunikasi pemasaran terpadu bagi perusahaan-perusahaan yang menghasilkan produk kebutuhan konsumen maupun produk industri.

Perusahaan harus menyediakan dana cukup besar setiap tahun untuk mengembangkan dan memelihara database yang berisi informasi mengenai alamat dan/atau nomor telepon pelanggan atau calon pelanggan. Mereka menggunakan telemarketing untuk 
menelepon pelanggan secara langsung dan berusaha menjual produknya. Pengelola pemasaran dewasa ini juga mengirim surat kepada pelanggan mulai dan surat biasa yang sederhana, lembaran promosi (flyers), brosur, katalog dan bahkan videotape dalam upaya menginformasikan mengenai barang dan jasa yang ditawarkan. Teknik pemasaran langsung juga digunakan untuk mendistnibusikan contoh produk (sampel), khususnya kepada konsumen yang telah menggunakan produk yang dihasilkan perusahaan saingan.

\subsubsection{PUBLIC RELATIONS}

Kegiatan hubungan masyarakat atau public relations (PR) adalah upaya pengelola media penyiaran untuk membentuk persepsi masyarakat atas media penyiaran. Dengan demiklan, kegiatan PR ditujukan kepada segala aktivitas yang ditujukan untuk membentuk persepsi yang dikehendaki. (Morrisan, 2009 : 431)

Media penyiaran adalah lembaga yang berada di tengah masyarakat dan tentu saja media penyiaran akan selalu berhubungan dengan masyarakat. Masyarakat yang menjadi fokus perhatian media penyiaran adalah audiennya sendiri dan juga audien lainnya yang memiliki potensi untuk dapat ditarik ke stasiun sendiri. Dengan demiklan, audien adalah publik utama media penyiaran. Melalui kegiatan PR hubungan baik dengan audien harus terus-menerus dijaga.

Dalam upaya menjaga hubungan baik dengan khalayak, media penyiaran harus melakukan berbagai hal agar masyarakat menganggap suatu media penyiaran sebagai media yang bertanggung jawab, dapat dipercaya dan lembaga yang berharga bagi masyarakat.

Dalam upaya meningkatkan promosi terhadap media penyiaran melalui kegiatan PR ini maka media penyiaran dapat melakukan sejumlah kegiatan antara lain yaitu:

1. Jumpa pers. Bila media penyiaran memiliki informasi atau kegiatan penting yang perlu diketahui masyarakat, maka media penyiaran bersangkutan dapat melakukan jumpa pers dengan mengundang reporter dan fotografer dari seluruh media massa. Pada jumpa pers ini biasanya manajer umum dan pejabat terkait ikut hadir untuk mengumumkan sesuatu dan menjawab pertanyan yang diajukan pers. Cendera mata atau press kit biasanya dibagikan pada kesempatan ini. 
2. Kehadiran orang terkenal. Stasiun radio dan televisi harus selalu berupaya untuk mendapatkan publisitas seoptimal mungkin jika ada orang terkenal (selebritis) berkunjung ke suatu kota, daerah atau komunitas yang terdapat di sekitar stasiun bersangkutan, terlebih lagi jika stasiun itu turut serta mengorganisir kunjungan selebritis atau menjadi salah satu sponsor dalam kegiatan yang mengundang selebritis. Dalam acara seperti ini selebritis biasanya setuju untuk diwawancarai di stasiun penyiaran dan melakukan pengambilan gambar untuk pengumuman promosi misalnya mengucapkan slogan stasiun penyiaran bersangkutan.

3. Menonton program. Stasiun televisi dapat mengundang reporter surat kabar dan pengamat media menonton program baru yang akan ditayangkan di stasiun televisi bersangkutan. Reporter biasanya akan menulis laporan atau artikel mengenai program itu di surat kabarnya. Laporan wartawan di surat kabar mengenai program baru diharapkan dapat memberikan dampak positif sehingga akan menarik audien.

4. Pelayanan masyarakat. Berbagai kegiatan dapat dilakukan dalam kegiatan pelayanan masyarakat, misalnya turut serta dalam kegiata amal atau kegiatan penggalangan dana. Dalam kegiatan ini stasiun penyiaran dapat mengirimkan presenter/penyiar, reporte dan staf lainnya untuk turut serta berpartisipasi. Kegiatan lain, misalnya, meminta para eksekutif media penyiaran untuk memberikan ceramah di sekolah, perguruan tinggi dan organisasi kemasyarakatan lainnya. Selain itu, stasiun penyiaran dapat mengundang masyarakat untuk berkunjung ke stasiun dan bertemu dengan para staf penyiaran. Penghargaan atau piala yang pernah dimenangkan stasiun bersangkutan dapat dipertunjuk ka sehingga dapat dilihat setiap pengunjung.

\subsection{PROMOSI PENJUALAN}

Promosi penjualan secara umum dapat dibedakan menjadi dua bagian, yaitu promosi penjualan yang berorientasi kepada audien atau konsumen (conszmer-oriented sales promotion) dan promosi penjualan yang berorientasi kepada perdagangan (trade-oriented sales promotion). Promosi penjualan yang berorientasi kepada audien atau konsumen ditujukan kepada pengguna atau pemakai akhir suatu barang atau jasa yang mencakup 
pemberian kupon, pemberian sampel produk, potongan harga, undian berhadiah, kontes, dan sebagainya.

Stasiun televisi terkadang melakukan promosi penjualan semacam ini dengan cara memberikan hadiah bagi audien yang tengah menonton program televisi stasiun bersangkutan. Instrumen promosi semacam ini dapat menarik minat audien untuk terus menonton sehingga meningkatkan minat audien menonton program suatu stasiun penyiaran dalam jangka pendek.

Promosi penjualan yang berorientasi kepada perdagangan ditujukan kepada pihakpihak yang menjadi perantara pemasaran (marketin intermediaries) yaitu: para pedagang pengecer (retailer), pedagang besar dan distributor, dan bagi media penyiaran adalah perusahaan iklan atau biro iklan. Bentuk-bentuk promosi jenis ini antara lain berupa pengaturan atau penyesuaian harga jual slot iklan (price deal), pemberian insentif atau bonus dan sebagainya yang semuanya bertujuan untuk mendorong perusahaan iklan untuk memasang iklan di media penyiaran bersangkutan.

Media penyiaran memilih menggunakan promosi penjualan dibandingkan jenis promosi lainnya karena dua alasan utama yaitu:

1. Pertama, jika audien tidak memiliki loyalitas pada suatu stasiun atau program tertentu dan audien lebih peka kepada insentif yang ditawarkan.

2. Kedua, jika terdapat kecenderungan pemasang iklan dan/atau perusahaan iklan memiliki posisi yang lebih kuat dibandingkan stasiun penyiaran sehingga mereka dapat lebih menuntut stasiun penyiaran untuk memberikan lebih banyak promosi penjualan dan insentif lainnya kepada pemasang iklan.

\subsection{INTERACTIVE/INTERNET MARKETING}

Media interaktif memungkinkan terjadinya arus informasi timbal balik yang memungkinkan pengguna dapat berpartisipasi dan memodifikasi bentuk dan isi informasi pada saat itu juga (real time). Tidak seperti bentuk tradisional komunikasi pemasaran seperti iklan yang komunikasinya bersifat satu arah, media interaktif memungkinkan pengguna melakukan berbagai fungsi seperti menerima dan mengubah informasi dan gambar, mengajukan pertanyaan, menjawab pertanyaan dan tentu saja melakukan pembelian. 


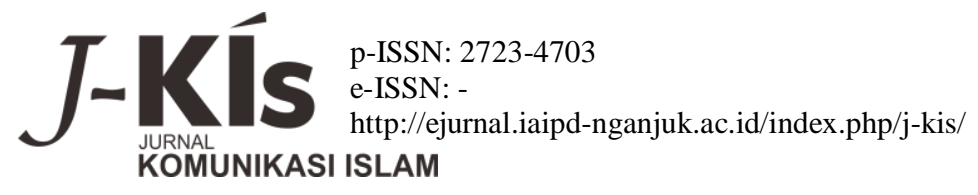

Volume 01, Nomor 01

Juni 2020

Kehadiran Internet tidak saja telah mengubah cara-cara perusahaan dalam merancang dan melaksanakan strategi bisnis dan pemasaran namun jug,a memengaruhi program komunikasi pemasaran mereka. Ribuan perusahaan di dunia, mulai dari perusahaan multinasional raksasa hingga perusahaan lokal skala kecil, dewasa ini telah mengembangkan website atau situs web untuk mempromosikan barang dan jasa mereka. Bagi media penyiaran, Internet tidak saja berfungsi untuk menyampaikan informasi dan melakukan interaksi dengan audien dan pemasang iklan, namun juga memberikan hiburan melalui fasilitas yang ada di situs web kepada audien mereka.

Internet saat ini sudah menjadi media iklan yang menarik. Redaksi pemberitaan media penyiaran kerap menggunakan situs web mereka untuk menyebarkan berita yang mereka dapatkan. Banyak praktisi promosi dan pemasaran mengiklankan produk mereka baik di situs web sendiri maupun di situs web milik perusahaan lain. Dapat dikatakan Internet merupakan media yang bahkan dapat digunakan untuk melaksanakan seluruh elemen bauran promosi. Selain digunakan untuk beriklan, Internet juga dapat digunakan untuk melakukan kegiatan promosi bentuk lainnya seperti promosi penjualan dengan kupon, kontes dan undian secara online. Praktisi promosi dan pemasaran juga menggunakan Internet untuk melakukan pemasaran langsung, penjualan personal serta kegiatan hubungan masyarakat secara lebih efektif dan efisien.

\subsection{PENJUALAN PERSONAL}

Elemen terakhir dan bauran promosi atau promotional mix adalah penjualan personal atau personal selling, yaitu suatu bentuk komunikasi langsung antara media penyiaran yang biasanya diwakili oleh seorang tenaga penjualan/pemasaran media penyiaran bersangkutan dengan calon pemasang iklan atau sponsor (person-to-person communication). Dalam hal in penjual berupaya untuk membantu atau membujuk calon pemasang iklan untuk membeli slot iklan pada program yang ditawarkan.

Tidak seperti iklan, penjualan personal melibatkan kontak langsung antara penjual dan pembeli slot iklan, baik secara tatap muka ataupun melalui alat telekomunikasi seperti telepon. Melalui interaksi secara langsung ini maka pihak penjual dapat melihat dan mendengarkan tanggapan atau respons pemasang iklan. Dalam hal in tenaga pemasaran 


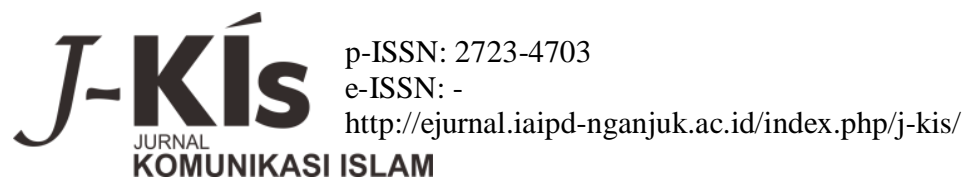

dapat langsung memodifikasi informasi yang harus disampaikannya setelah menerima tanggapan dan calon pemasang iklan.

Komunikasi yang bersifat individual dan personal dalam penjuala personal ini memungkinkan pihak penjual menyesuaikan pesan berdasarkan kebutuhan khusus atau situasi khusus calon pemasang iklan atau perusahaan sponsor. Penjualan personal memungkinkan terjadinya umpan balik secara langsung dan lebih tepat karena dampak dari presentasi penjualan yang dilakukan dapat dinilai dan reaksi calon pemasang iklan atau perusahaan sponsor. Jika umpan balik yang terjadi dinilai kurang baik, maka penjual dapat memodifikasi pesan-pesannya. Penjualan personal juga dapat ditujukan kepada calon pembeli yang dinilai paling potensial dan paling prospektif untuk menjadi pelanggan di masa depan.

Rencana promosi media penyiaran disusun dengan melibatkan bagian lain pada media penyiaran yaitu: manajer promosi, manajer umum, manajer program, manajer pemasaran, dan terkadang manajer pemberitaan. Rencana yang telah tersusun itu kemudian dilaksanakan oleh bagian promosi.

Menurut Pringle-Starr-McCavitt (1991) dalam melaksanakan rencana yang telah disusun, bagian promosi harus mengambil enam langkah yaitu:4 (Morrisan, 2009 : 421)

a. Yang pertama menentukan susunan demografis dan karakteristik audien yang terdapat di wilayahnya, serta menentukan jumlah (persentase) audien yang dikuasai media penyiaran sendiri dibandingkan dengan jumlah audien yang dimiliki media penyiaran saingan.

b. Yang kedua mencari tahu mengapa audien memilih stasiun sendiri dan mengapa audien lainnya memilih stasiun saingan. Perlu diketahui jawaban, mengapa khalayak sasaran yang diharapkan, belum juga bisa ditarik menjadi audien stasiun sendiri.

c. Kemudian perhitungkan kekuatan dan kelemahan stasiun sendiri serta kedudukan (positioning) stasiun untuk menarik audien yang diinginkan.

d. Yang keempat yaitu susun rencana untuk mengatasi kelemahan yang ada dan bagaimana memperbaiki kelemahan itu.

e. Selanjutnya melaksanakan rencana,

f. Dan yang terahir lakukan evaluasi atas efektivitas rencana dan jika perlu. 


\section{METODE PENELITIAN}

\section{Metode Pengumpulan Data}

Metode pengumpulan data merupakan teknik atau cara-cara yang dapat digunakan peneliti untuk mengumpulkan data (Rachmad, 2009, p.93). Untuk menunjang keberhasilan penelitian ini terdapat 4 teknik pengumpulan data yang akan dilakukan yaitu (Creswell, 2009 : 181):

1. Wawancara, jenis wawancara yang digunakan ialah wawancara semistruktur dimana peneliti mempunyai daftar pertanyaan tertulis tetapi memungkinkan untuk menanyakan pertanyaanpertanyaan secara bebas, yang terkait dengan permasalahan (Rachmad, 2009, p.99). wawancara ini lebih mirip seperti percakapan informal yang tidak dibuat-buat. Metode ini bertujuan untuk memperoleh bentuk-bentuk tertentu dari informasi yang ingin digali. Setiap susunan pertanyaan dan kata akan berbeda untuk setiap informannya. Perbedaan ini mengarah kepada ciri-ciri pribadi dari setiap informan. Wawancara tidak semistruktur bersifat luwes dan bersahabat. Susunan pertanyaan dapat berubah sewaktu-waktu menyesuaikan dengan kondisi saat berlangsungnya wawancara.

Teknik wawancara ini dilakukan pada subyek penelitian yang memiliki pengalaman dibidangnya, dan mampu memberikan konseptualisasi permasalahannya yaitu :

a. H. Rofik Huda : Direktur Utama

b. Ita Yani : Manager Bisnis

c. Romi Jatmiko : Manager Program

2. Observasi adalah dimana mengamati perilaku dan kegiatan subyek penelitian di lapangan. Observasi dalam penelitian dilakukan dengan cara mengamati kegiatan komunikasi pemasaran yang dilakukan di radio Andika . Pada penelitian ini menggunakan jenis observer sebagai periset, peneliti atau periset adalah orang luar yang netral yang mempunyai kesempatan untuk bergabung dalam kelompok dan berpartisipasi dalam kegiatan dan pola hidup kelompok tersebut sambil melakukan pengamatan (Rachmad, 2009, p.111).

3. Dokumen, dalam hal ini peneliti memperoleh dokumentasi diantaranya bisa dari dokumen perusahan misalnya laporan kerja, laporan kegiatan Pemasaran. Dokumentasi digunakan 


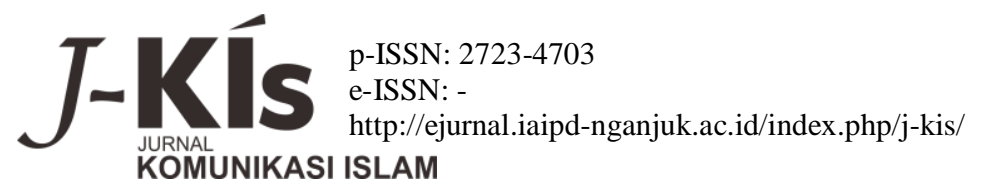

sebagai bukti tambahan pendukung data-data yang berkaitan dengan proses strategi komunikasi pemasaran radio Andika .

4. Materi audio atau visual, data yang dimaksud disini adalah berupa gambar, foto atau rekaman suara yang dapat ditranskrip dan menjadi bukti kegiatan trategi pemasaran di radio Andika.

\subsubsection{Jenis Sumber Data}

Data dalam penelitian ini, jenis data yang dikumpulkan terbagi menjadi 2 bagian yaitu data primer dan data sekunder. Data primer dalam penelitian ini diperoleh melalui wawancara mendalam terhadap informan dan observasi. Sedangkan data sekunder merupakan segala bentuk dokumentasi atau bukti sumber tertulis yang relevan dan dapat digunakan untuk mendukung penelitian.

\subsubsection{Metode Analisis Data}

Seperti yang sudah dijelaskan pada metode penelitian, bahwa penelitian ini adalah penelitian kualitatif. Peneliti akan mencari data sebanyak mungkin mulai dari pengumpulan informasi-informasi dan memasukkan kedalam bentuk data, kemudian peneliti akan melakukan pemilahan data yang tidak begitu penting dalam penelitian ini. Kemudian peneliti akan melakukan kajian mendalam terhadap data yang dipilih dan diolah untuk disajikan. Seperti teknik analisis milik Miles and Huberman, dimana pada teknik analisis ini teoritisasi memperlihatkan hubungan antar kategori yang kemudian dikembangkan atas dasar data yang diperoleh ketika penelitian di lapangan berlangsung. Karenanya, antara kegiatan pengumpulan data dan analisis data menjadi tak mungkin dipisahkan satu sama lain. Keduanya berlangsung secara serempak seperti yang telah digambarkan Miles dan Huberman berikut ini:

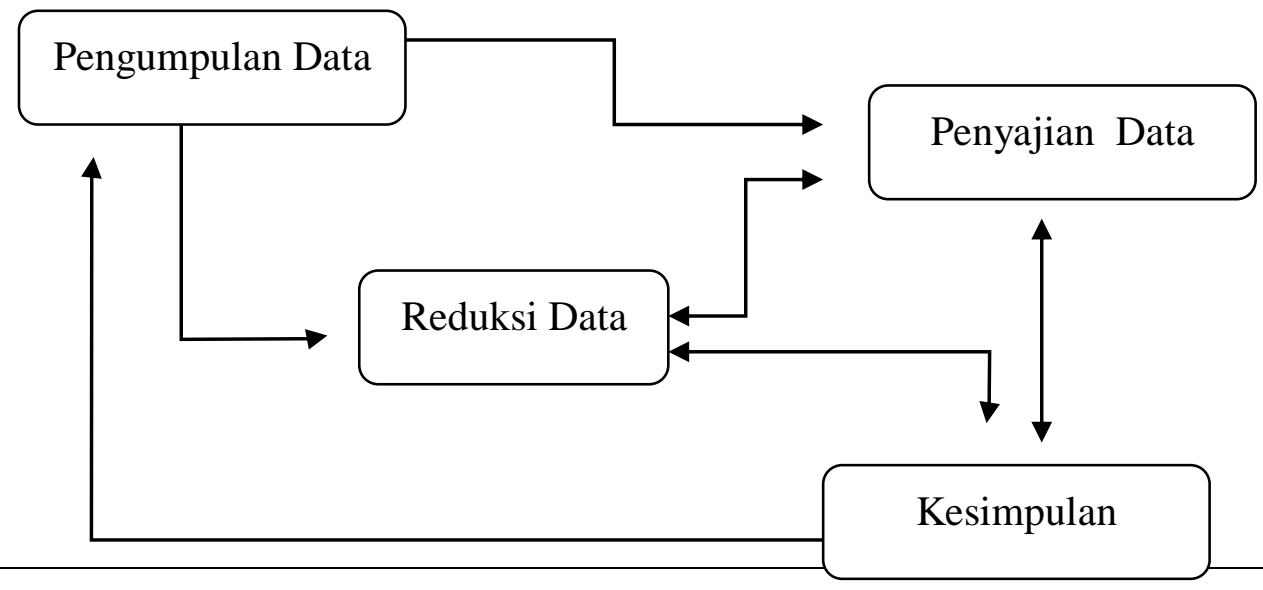


Dalam menganalisis terdapat sifat interaktif antara pengumpulan data dengan analisis data. Lebih jelasnya masing-masing komponen didefinisikan sebagai berikut :

1. Data Collection atau pengumpulan data adalah berbagai data yang telah dikumpulkan dilapangan baik itu hasil observasi, wawancara, dokumentasi dan materi audio visual yang terkkait dengan proses strategi komunikasi pemasaran radio Andika Periode 2014-2016. Dalam pengumpulan data, peneliti melakukan perbandingan perbandingan apakah data yang diperoleh dilapangan dapat memperkaya data bagi tujuan konseptualisasi, kategorisasi, ataukah teoritisasi.

2. Data Reduction, setelah sejumlah data yang diperlukan berhasil dikumpulkan, data tersebut perlu direduksi atau diolah. Pengolahan data ini mencakup mengikhtiarkan hasil pengumpulan data selengkap mungkin, dan memilah-milahnya kedalam satuan konsep tertentu, kategori tertentu, atau tema tertentu.

3. Display Data atau penyajian data, setelah hasil reduksi data selesai maka selanjutnya hasil tersebut diorganisasikan ke dalam masingmasing kategori. Display data pada penelitian kualitatif ini pemaparan hasil penelitian yang menggambarkan fenomena atau keadaan sesuai dengan data yang telah direduksi.

Conclution drawing and Verifiying, ini adalah langkah terakhir yakni dengan menarik kesimpulan. Kesimpulan diambil dari hasil penelitian dan pembahasan yang mempertegas hasil dari temuan dilapangan tentang proses strategi komunikasi pemasaran radio Andika Periode 2014-2016 


\section{HASIL DAN PEMBAHASAN}

Hasil dari penelitian pada radio Andika, mengenai strategi komunikasi pemasaran periode 1014-2016 dengan mewawancarai beberapa informan yaitu :

Tabel 4.3. Tabel Informan

\begin{tabular}{|c|c|}
\hline Nama & Bagian \\
\hline H. Rofik Huda & Direktur Utama \\
Ita Yani & Manager Bisnis \\
Romi Jatmiko & Manager Program \\
& \\
\hline
\end{tabular}

\section{Sumber: Olahan peneliti}

Dari hasil wawancara yang dilakukan peneliti ditemukan data-data sebagai berikut:

Radio Andika merupakan radio pertama di Kediri yang menggunakan frekuensi FM, hal tersebut terjadi pada tahun 1990. Itu merupkan suatu momentum yang besar bagi radio tersebut, akan tetapi radio Andika gagal memanfaatkan momen besar tersebut. Radio Andika yang pertama menggunakan format FM seharusnya menjadi nomor 1 di kota Kediri. Hal tersebut di gambarkan dengan bangunan Andika, sejak tahun 1990 sampai tahun 2003 Andika menempati bangunan kontrak, tower pemancar juga belum punya.

Seperti petikan wawancara dengan Dirut radio Andika dibawah ini:

"Andika itu dulu radio no.1, FM Pertama, bayangkan lo, tahun 1990, FM Pertama,mustinya itu momentum besar itu, gak ada saingan too, FM satu-satunyanya, kudune no.1......... Mulai tahun 90-2003 Andika ngontrak" 


\section{$J$-Kíls}

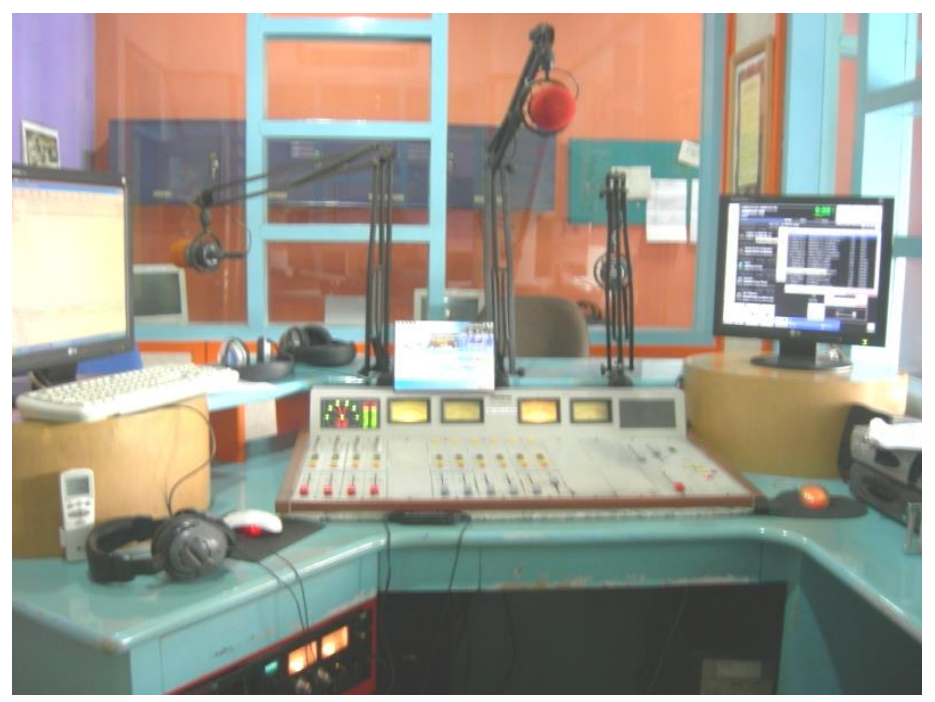

Gambar 4.6 . Studio radio Andika di Gedung Lama Sumber: Olahan Peneliti

Pada tahun 2000an sampai 2009 merupakan masa kejayaan bagi radio Andika, dinilai dari bisnisnya namun tidak dilihat dari stasiun penyiarannya. Pada masa itu bisnis radio Andika bertolak dengan jumlah pendengar, pendengar sedikit tetapi jumlah iklannya banyak. Hal tersebut terjadi dikarenakan salah seorang pemilik dari radio Andika adalah pemilik agency iklan Nasional yaitu Kalbe dan Tempo Scanpasific. Hal tersebut yang menjadikan radio Andika mendapatkan jumlah iklan yang besar, walaupun tidak diimbangi dengan jumlah pendengar. 2010 merupakan puncak dari dari kejayaan radio Andika.

Namun selang 1 tahun yaitu pada 2011, radio Andika mengalami kemunduran dari segi bisnis. Terjadi pengurangan belanja iklan radio yang dilakukan oleh Kalbe dan Tempo Scanpasific, dimana kedua perusahaan tersebut yang menjadi pengiklan besar di radio Andika dengan berbagai macam produknya.

Pada tahun 2014, bencana alam Gunung Kelud meletus, dahsyatnya ledakan dan semburan debu vulkanik dirasakan sampai di Jawa Tengah. Pada waktu itu tanpa ada perencanaan bisnis, tanpa ada perencanaan program, radio Andika melakukan siaran jurnalistik. Semua isi dari siaran tentang Gunung Kelud, tidak ada guyonan, tidak ada dangdutan, semua bicata tentang Gunung Kelud. Pada saat itu ada keraguan yang dialami oleh karyawan Andika, karena sama tidak memiliki pengalaman melakukan siaran 
jurnalistik. Namun keyakinan tersebut tumbuh karena Andika menjadi satu-satunya yang melakukan siaran news. Tidak ada pesaing dari radio lain dan tidak akan ada pembanding pada saat itu.

Kacaunya siaran pada waktu itu dirasakan oleh manager program, Romi, yang pada saat itu belum bergabung dengan radio Andika dan hanya menjadi pendengar. Berikut kutipan wawancara:

"Ini radio memberanikan diri bikin news, pada waktu itu, saya ingin ketawa, karena aku pernah ada di radio news, pernah diradio musik, jadi aku merasakan betul transisi ini ambiennya ngawur ini orang-orang. Mereka melakukan ini radio Andika ini, melakukan siaran dengan $\mathrm{OB}$ fan dari sana. Jadi kelihatan betul gamangnya reporter live report. Kemudian yang ada di ruang siaran, biiuh ngisin-ngisini."

Format jurnalistik yang di usung radio Andika adalah menerima laporan-laporan dari korban kelud. Jumlah korban jiwa, jalan rusak sampai pasokan logistik kedaerah-dearah yang terkendala, menjadi laporan dari masyarakat.

Saat setelah momen Kelud meletus terlewati, tejadi keraguan dalam managemen radio Andika, apakah akan meneruskan format jurnalistik atau berbalik lagi ke radio Entertaiment. Hal yang ditakuti adalah kurangnya partisipasi dari masyarakat untuk melaporkan kejadian disekitar. Karena masyarakat di wilayak Kediri berada di kelas B dari segi potensi ekonomi, setara dengan Malang, Sidoarjo. Ketakutan tersebut juga dirasakan oleh manager bisnis, mbak Ita:

"Kalo pak rofik sih, secara pribadinya memang ruh nya disitu, dan dia melihat disini belum ada, yaudah banting setir pisan. Jangan dikira kita nggak ndredeg, ya ndredeg juga, engko gek gak enek sing ngrungokne, Cuma ternyata kan wes berhasil di ge menebus semua dan kita bisa membuktikan bener-benar dijalur ini dan konsisten.”

Dengan kebulatan tekad direktur utama, radio Andika merubah formatnya menjadi Citizen journalism. Ketakutan mengenai kurangnya partisipasi masyarakat tidak terjadi, 
setelah 3 bulan Informasi dari masyarakat mengenai gunung Kelud menurun, datanglah bulan ramadhan. Informasi berubah menjadi laporan mengenai harga bahan pokok, persiapan mudik, jalan macet dan laporan kecelakaan.

Setelah perubahan tersebut, jenis iklan diradio Andika mengalami perubahan. Saat masih dalam format entertaiment jenis iklan Spot mendominasi dengan $80 \%$ dari total keseluruhan pendapatan, kemudian Adlibs dengan 15\%, sementara untuk talk show hanya $5 \%$ dari total pendapata. Kemudia berubah menjadi Spot 40\% Adlibs 35\% dan talk show $25 \%$.

Tabel 4.4. Jenis Iklan

\begin{tabular}{|l|c|c|}
\hline Jenis iklan & Format Entertaimen & $\begin{array}{l}\text { Format } \\
\text { journalism }\end{array}$ \\
\hline SPOT & $80 \%$ & $40 \%$ \\
\hline ADLIBS & $15 \%$ & $35 \%$ \\
\hline TALKSHOW & $5 \%$ & $25 \%$ \\
\hline
\end{tabular}

Sumber: Olahan Peneliti

Dalam skala pengiklan, di Andika telah berubah yang saat measih berformat entertaiment didominasi oleh iklan dan produk-produk berskala Nasional, kini didominasi oleh pengiklan berskala lokal. Seperti iklan warung makan, toko bangunan, tempat hiburan, tukang pijit, jualan jamu yang memiliki skala lokal. Menurut Dirut Andika hal tersebut merupakan perubahan karakter pengiklan, seperti tertuang dalam kutipan dibawah ini:

"karena radionya lokal pengiklannya lokal. Sekarang ini Andika pengiklannya lokal-lokal. jadi uang sekian itu, tapi bukan semua...kemarin $i k u$ kata ita itu, kira-kira $70 \%$ nya. 2010 lokalnya gak sampe 20\%, Nasionalnya 80\%. Sekarang dibalik kira-kira 30-70 lah... itulah perubahan karakter pengiklannya."

Senada dengan pernyataan di atas, Ita sebagai manager bisnis radio Andika menyatakan bahwa: 
"sekarang ini banyak lokal, sebenernya kalo Nasional dibandingkan tahun-tahun lalu memang turun dia,tetapi ini adalah tren......."

Grafik bisnis Andika berangsung memulih, ada perubahan naik dalam periode tahun 2014 pertengahan sampai tahun 2016.

“.....sampai 2016 itu memecahkan rekor pendengar, 2015 rekor, 2016 rekor juga....jadi artine yang bikin radio itu ya tiga itu...ya programnya,stationnya,pendengarnya, trus kemudian pengiklannya....."

Pada tahun 2015 jumlah pendapatan radio Andika melebihi tahun 2010, dimana pada tahun tersebut merupakan puncak kejayaan saat masih berformat Entertaiment. Dan pendapatan di tahun 2016, naik 30\% dari pendapatan di tahun 2015. Seperti dikutip dalam wawancara dengan direktur utama berikut:

“2010 kan puncaknya, 2012 itu jatuh kira-kira tinggal 70\% dari tertinggi, 2013 itu naik dikit, 1,3. 2014 itu tetep sama seperti sebelumnya, 2015 langsung naik ke melewati tahun 2010. Jadi langsung terlewati angka di tahun 2010. 2016 melewati lagi 30\% dari 2015. Jadi pernah turun 30\%, trus naik lagi sekian....kenaikan tertinggi dari 2015 ke 2016. 2015 sama sekitar 1,7 itu tadi, 2016 naiknya 30\% sekitar 2,4 sekian. Maka target kita 2017 itu 2,5 ato 2,7 nyampe lah.kan targetnya perusahaan di gae ngene, misalkan targetnya 2,4 itu tugasnya departemennya ita, dia manajer bisnis, dia atur menjadi 12 bulan, nah ketemunya 200, maka perbulan harus dapat 200, ketika 200 nya gak tercapai maka bulan berikutnya dia harus 200 sekian nambahi kekurangan bulan sebelumnya. Indikasinya Januari Februari udah lewat itu"

Tabel 4.5. Pendapatan Andika

\begin{tabular}{|c|c|c|}
\hline No & \multicolumn{1}{|c|}{ Tahun } & \multicolumn{1}{c|}{ Pendapatan } \\
\hline 1 & 2014 & 1,3 Milyar \\
\hline 2 & 2015 & 1,7 Milyar \\
\hline 3 & 2016 & 2,4 Milyar \\
\hline
\end{tabular}


Sumber: Olahan peneliti

Indikator yang dijadikan oleh radio Andika dalam menilai kesuksesan perusahaan penyiaran ada 3 macam yaitu:

Yang pertama yaitu program nya, jika programnya bagus dan dibutuhkan masyarakat, akan menarik pendengar. Radio Andika berusaha membuat sebuah program yang bertujuan memberi manfaat bagi pendengar. Jadi tidak hanya memberikan informasi yang disampaikan oleh pendengar, namun akan di tindaklanjuti dengan memberi solusi. Seperti dikutip dalam wawancara dengan dirut Andika:

"Selalu saya katakan pokoknya,yang penting siaran kalian memberi manfaat. Citizen journalism di Andika itu saya kembangkan ke akses manfaat. Misalkan begini, sebenarnya citizen journalism itu sudah selesai ketika $5 \mathrm{~W}+1 \mathrm{H}$ terjawab . misalkan ada tabrakan di Papar, tugasnya penyiar adalah menggali dari pendengar yang telepon tadi , yang reporter tadi, 5W $1 \mathrm{H}$ nya tercapai ya. Di Andika tidak boleh berhenti di citizen journalism itu, harus ada manfaatnya. Apa itu, sudah ada polisi belum, segera gatekeeper menghubungi polisi, agar polisi segera datang ke TKP”

Program juga menjadi alasan kuat bagi manager marketing dalam memasarkan Andika:

“jadi karena kita kuat di program. Jadi ketika orang perlu, orang akan datang sendiri Jadi program tetap menyimpulkan dan tetap memegang ini semua tu karena program, jadi karena eksistensi program kita yang luar biasa itu................ menjadi radio seperti itu akhirnya mendatangkan berkah juga untuk kita kan, apa ya kalo dikatakan profit ya itu. Ketika kita bisa memberikan sesuatu, akhirnya ya itu, kita jadi gak butuh didengar tapi juga dibutuhkan"

Senada dengan manager program, bahwa siaran harus memiliki manfaat, seperti tersirat dalam wawancara dengan Romi, sebagai berikut: 
"Saya diberitahu teman saya, kalo menginformasikan berita kehilangan sebaiknya diradio Andika saja...."

Indikator yang kedua adalah dari pendengarnya, pendengar Andika tidak sebanyak dari kompetitor di daerah, akan tetapi memiliki loyalitas dalam mendengarkan. Seperti dikutip dari wwancara dengan dirut sebagai berikut

"Survey terakhir, gak ada setengahnya pendengar dari Wijangsongko Dengan coverage yang sama lo ya, sampe Mojokerto, Krian, kalah lah, jumlahnya lo ya, tapi penetrasinya gak ada apa-apanya Wijangsongko. Tingkat kepercayaan publik terhadap stationnya itu tinggian saya. Jumlah gak akeh tapi orangnya loyal. karena orang-orang berpendidikan radio itu bicara programnya, statusnnya, pendengarnya itu loyalitas, jumlah, macem-macem. jumlah yang banyak belum tentu loyal kalo Andika jumlahnya gak banyak tapi pendengarnya loyal. itu namanya segmentasi”

Meskipun dari segi jumlah sedikit namun pendengar di Andika merupakan orang yang aktif, aktif dalam artian menyampaikan informasi-informasi. Seperti di kutip dari wawancara dengan dirut Andika:

“ .pendengar saya mungkin hanya 10 orang, misal pak man, tapi dia gak kirim salam ke bu muta dll, tapi dia menyampaikan, awas ada kecelakaan disini, hindari jalan ini. Engko sak jam neh dia telefon, awas ada banjir di Tulungagung, selalu memberikan manfaat, informasi, meskipun mungkin pendengarku gak banyak kan yang aktif, tapi dia selalu bergerak"

Indikator yang ketiga adalah dari bisnisnya, Indikator ini menilai kesuksesan sebuah media penyiaran di ukur dari pendapatan yang di peroleh perusahaan dari pengiklan. Radio Andika merupakan radio yang sukses dalam bisnisnya. Kesuksesan radio Andika 
dapat terlihat dari fisik, radio Andika telah memiliki gedung sendiri dan atribut yang dimiliki. Seperti di kutip dari wawancara dengan dirut Andika:

"Andika dalam tempo 3 tahun udah berhasil, bisnisnya berhasil. kayak gedung dll itu kan....."

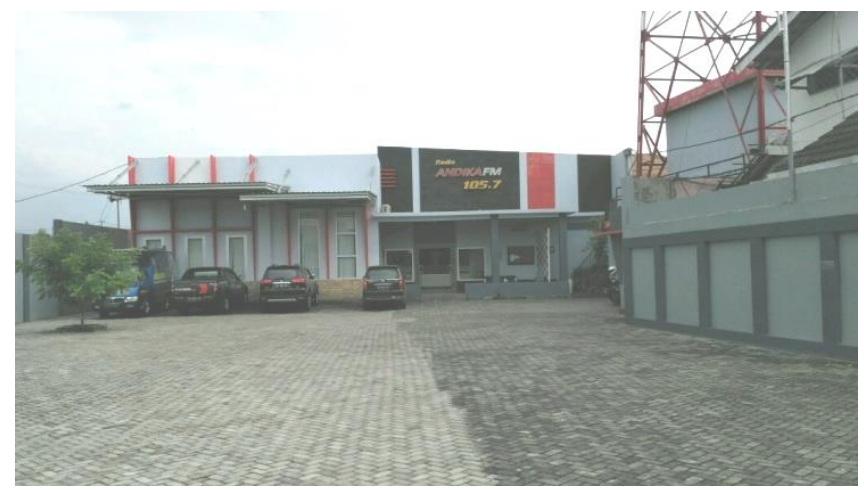

Gambar 4.6 . Studio radio Andika di Gedung Baru

Sumber: Olahan Peneliti

Kesuksesan dalam tiga indikator tersebut dipaparkan dirut dalam wawancara, berikut kutipan pernyataan tersebut:

"Perkembangane kok apik, nah, radio itu berhasil itu ada 3 referensi, 3 hal indikator itu sukses: Pertama dari program nya, dari radionya, teknologi,kedua dari pendengarnya pendengar itu bisa macem2, jumlah maupun loyalitasnya.Yang ketiga itu dari bisnisnya Ketiganya itu alhamdulillah Andika wes simetris perjalanannya."

Kesuksesan tersebut tidak terlepas dari fasilitas yang diberikan kepada publik untuk mengakses berita dan menyampaikan berita. Terdapat 3 line telepon yang dapat digunakan pendengar untuk melaporkan informasi. Terdiri dari 1 jaringan kabel (ptsn) dan 2 jaringan seluler (Telkomsel dan Indosat). Publik juga dapat menyampaikan informasi lewat WhatsUp, SMS dan pesan Facebook di fanpage AG243.

Informasi yang disampaikan oleh pendengar tidak terlewat begitu saja, setelah disampaikan di radio. Publik dapat mengakses berita yang telah terlewat, dengan membuka 
fanpage, website dan twitter radio Andika karena informasi yang telah disampaikan akan diposting dalam jejaring sosial dan web Andika FM. Jadi setiap informasi yang terlewatkan dapat diakses kembali oleh publik. Dalam kutipan dengan dirut Andika berikut:

"Kita mengelola media sosial memang sebenernya juga manbantu promosi, menambah jumlah pendengar, AG243 itu sekarang sudah tembus 100 ribu like. Saya memanfaatkan media sosial dulu awalnya itu dulu untuk memberi materi akses mendengar radio Andika kalo tidak punya sms, bisa lewat facebook aja waktu mengirim. Disisi lain , kalo kelewatan mendengarkan Andik lihatlah facebook. Makanya kadang-kadang orangorang itu tau meski tidak mendengarkan Andika, itu darimana, dari facebooknya Andika"

Informasi yang disampaikan pendengar melalui beberapa tahapan sebelum ahirnya di udarakan. Tahapan tersebut adalah pendengar menghubungi radio Andika, kemudian masuk di gatekeeper untuk didata tentang isi yang akan di sampaikan dengan berpegang pada 5W $1 \mathrm{H}$, baru setelah informasinya yang dibutuhkan lengkap, informasn bisa langsung onair atau diwakilakn oleh gatekeeper. Setelah itu informasi diposting dalan sosial media. Hal tersebut tertuang dalam wawancara dengan dirut Andika sebagai berikut:

“Orang masuk, ditanya sama temen-temen, kepentingannya apa-apa kalo sudah clear baru dia boleh on air. Saat on air itu penyiar dibantu oleh team gatekeeper untuk menanya 5W 1H plus ke solusinya. Selesai itu konsumsi beritanya baru untuk ke FB. Hasil fb ini dapat dibaca lagi oleh penyiar satu jam kemudian"

Demikian temuan data yang peneliti dapat setelah melakukan penelitian di radio Andika. Dengan tagline informasi dan solusi serta mengandalkan dukungan penuh dari pendengar, menjadikan kami "berbeda" dengan radio lain. 105,7 Radio Andika adalah radio pertama Jawa Timur diluar Surabaya, yang mengusung konsep Citizen journalism secara total dan konsisten

\section{DAFTAR PUSTAKA}

Albarran, Alan B. 2010. Management of Electronic Media : Fourth Edition.Boston : Wadsworth Alma, Prof. Dr. H. Buchari. 2013.Kewira usahaan. Bandung:Alfabeta. 
A. Shimp, Terence.Periklanan Promosi dan Aspek Tambahan Komunikasi Pemasaran.Jakarta:Erlangga.

Bungin, Burhan. 2008. Analisis Data Penelitian Kualitatif. Jakarta : PT. Raja Grafindo Persada. Kriyantono, Rachmat. 2009. Teknik Pramtis. Riset Komunikasi. Jakarta:Kencana

Kotler, Philip., \& Kevin Lane Keller. 2009. Manajemen Pemasaran : Edisi Ketiga Belas. Jakarta : Erlangga.

Machfoedz, Mahmud. 2010. Komunikasi Pemasaran Modern. Yogyakarta: Cakra Ilmu

Morissan. 2009. Manajemen Media Penyiaran : Strategi Mengelola Radio dan Televisi. Jakarta : Prenada Media Group.

Nugraha, Pepih. 2012. Citizen Journalism. Pandangan, Pemahaman, dan Pengalaman. Jakarta: Kompas Media Nusantara

Shimp. Terece.A. 2014. Komunikasi Pemasaran Terpadu. Dalam Periklanan dan Promosi.Jakarta: Salemba Empat.

Triartanto, Ius. Y. 2010. Broadcasting Radio : Panduan Teori dan Praktek. Yogyakarta : Pustaka Book Publisher

Yin, Robert K. 2008. Studi Kasus : Desain \& Metode. Jakarta : Rajawali Pers.

Sumber Lain:

Jurnal Komunikasi Universitas Atma Jaya 2004

www.andikafm.com

(http://www.radioprssni.com/prssninew/internallink/Program\%20Umum\%20PRSSNI\%202011.p $d f)$ 